\title{
The State of Economy of Cotabato City during the Implementation of Martial Law Pursuant to Proclamation No. 216
}

\author{
1,2,3 Mindanao State \\ University-Maguindanao, \\ Maguindanao, Philippines \\ ${ }^{1} d p a b d u l a @ m s u m a g u i n d a n a o$. \\ edu.ph, \\ 2eiramnyl0501@gmail.com, \\ ${ }^{3}$ TKSalipada@gmail.com
}

| Datuali P. Abdula ${ }^{1}$ | Lyn Marie Centeno² | Tahir K. Salipada ${ }^{3}$ |

\begin{abstract}
Mindanao was placed under Martial Law when President Rodrigo Duterte declared the suspension of the writ of habeas corpus on May 23, 2017 by virtue of Proclamation No 216. The call was made in an attempt to control the spread of threat brought about by the armed rebel Maute Group when they sieged Marawi City. Previous studies argued that a state is economically developed when the markets regulate themselves and the government has less intervention over it. It also concluded that dictatorship or strong political participation, when temporarily held, promote economic development. This study assessed the status of economy of Cotabato City as one of the areas of trade and commerce in Mindanao being affected by the implementation of Martial Law. Martial Law in the Philippines was always viewed as the military, headed by its Commander-in-Chief, the President, taking total control of the political power thereby inflicting negative impact on the state's economy. The economic status of Cotabato City during Martial Law implementation was evaluated specifically in terms of trades, investments, local employment and tourism. Results presented that despite of Martial Law period, Cotabato City's state of economy, particularly its activities on trades, investments, local employment and tourism, is high. This study showed that political intervention during the Martial Law implementation, does not affect the status of a city's economy. KEYWORDS

State of Economy; implementation; martial law; Proclamation No. 2016
\end{abstract}

\section{INTRODUCTION}

The Organization for Economic, Co-Operation and Development emphasized that the security industry and the economy simultaneously influence one another (OECD, 2004). The crime rates, threats brought about by terrorism, and illegal trade or trafficking affect the economic growth and development of a state. It also recognized the challenge for policymakers on how to address the increasing security requirements without hampering economic efficiency and the rights of the citizens.

On May 23, 2017, President Rodrigo Duterte declared Martial Law and suspension of the writ of habeas corpus for the entire Mindanao region by virtue of Proclamation No 216. The declaration resulted from the armed encounter between rebel Maute Group and the Armed Forces of the Philippines (AFP) that escalated in Marawi City.

In response to this proclamation, security measures such as AFP and PNP checkpoints along road networks in Mindanao and police visibility in key municipalities and cities were maximized. Cotabato City, has strictly implemented its existing Ordinance 4529 or the Discipline Ordinance in support to the declaration of Martial Law ensuring that every Cotabateño abides the law. "Discipline Hour Ordinance" was strictly imposed among the 
residents of the city along with the "No ID, No Entry" policy for local commuters entering the vicinity and the nightly Revitalized Operation and Neutralization of Drug Addiction (RONDA) patrol.

Hence, it was not the first time that the Philippines was placed Under Martial Law. On September 21, 1972, during the administration of President Ferdinand Marcos declared Martial Law "stressing the need for extra powers to quell the rising wave of violence allegedly caused by the communist rebels" which lasted for 14 years. Case studies conducted showed that Marcos's declaration of Martial Law affected the political and socio-economic standing of the Philippines.

Further, the Armed Forces of the Philippines (AFP) has a traditional role of defending the state and protecting the national sovereignty and territorial integrity. However, in early 1951 and during the Martial Law declaration of President Marcos, the AFP was tasked with its non-traditional role or the so-called developmental role. At that time, the AFP was to defeat communist insurgents while at the same time offering developmental projects to rebels who opted to return to the government side. Then, the AFPs' campaign plans are anchored to support national development, economic development and law enforcement (Acop, 2006).

As Richards (2001) cited, the military mostly always performs a significant role in the government being a source of repression against competing groups or civil unrest to some degree in non-democratic regimes. On the downside, military power is also viewed as threat most especially in developed countries where such power is superior. They are also considered as erest groups (Oslon, 1993). Accordingly, the existence of such interest groups in a democratic system could be detrimental to economic development.

In addition, there have been several studies conducted on the influence of political instabilities coming from military intervention and coalition periods on economic growth. Martial Law implementation is considered military intervention. It has been said that the Philippine economy dwindled during Marcos' Martial Law period. There were a lot of questions raised during those times, such as: How is Mindanao's economic growth? As a thriving city, was Cotabato able to cope up and continue its development programs and initiatives despite the existence of martial law? Were the employment rates, trades, investment opportunities, and tourism ventures positively or negatively affected?

In this regard, this study is conducted to assess the impact of Martial Law implementation on the economic growth and development of Cotabato City.

\section{RESEARCH METHOD}

This study utilized a descriptive-quantitative research design employing a survey questionnaire method in gathering data. The researcher constructed a survey questionnaire to obtain the purpose of the stud75 respondents were coming from random consumers, officials, and/or members of the City Planning and Development Office, City Tourism, Trade, Industry, and Investment Office, City Public Employment Service Office, and Barter Traders Association. These respondents were selected purposely on the basis of their knowledge and experiences relating to the information gathered.

The survey questionnaires were personally administered to the respondents. The statistical tools used in data gathering were: frequency count, mean, percentage, and ranking distribution. 


\section{RESULTS AND DISCUSSION}

\section{Demographic Profile of the Respondents}

The data gathered on the demographic profile of the respondents is presented in a tabular form in the following categories: sex, age, highest educational attainment, occupation, organization membership, religious affiliation and position held in the office/organization.

a. Sex of the Respondents

As shown in Table 1 column a, 32 of the total respondents were males with a percentage of $42.67 \%$ while 43 were females with a percentage of $57.33 \%$. Therefore, majority of the respondents in this study are females.

b. Age of the Respondents

As shown in Table 1 column b, ages ranging from 18 to 24 years old comprise of 33 from the total number of respondents with a percentage of $44 \%$. The average age of 75 respondents is 29 years old. Fifty-six (56) or $75 \%$ of the respondents are 31 years old and below.

c. Highest Educational Attainment of Respondents

As shown in Table 1 column c, 39 respondents have the highest educational attainment of College Graduate comprising 52\% out of the 75 respondents. Meanwhile, 21 respondents or $28 \%$ indicated Others which is composed of College Level and Undergraduate. Thus, most respondents of this research are College Graduates

d. Occupation of Respondents

As shown in Table 1 column d, 19 respondents have not indicated their occupation comprising 25.33 percent out of 75 respondents. However, 17 of the other 56 respondents were government employees representing $22.67 \%$. Hence, most of the respondents of this study are government employees.

e. Organization Membership of Respondents

As shown in Table 1 column e, 60 respondents are not affiliated with any organization with a percentage of $80 \%$. However, 5 respondents or $6.67 \%$ indicated their membership with the City Government of Cotabato. Therefore, majority of the respondents of this study have no organizational membership.

Table 1. Frequency and Percentage Distribution of Respondents

\begin{tabular}{|c|c|c|c|c|c|c|c|c|c|c|c|c|c|c|}
\hline a. Sex & $\mathbf{f}$ & $(\%)$ & $\begin{array}{l}\text { b. Range } \\
\text { of Age }\end{array}$ & $\mathbf{f}$ & $(\%)$ & $\begin{array}{l}\text { c. Highest } \\
\text { Educational } \\
\text { Attainment }\end{array}$ & f & $(\%)$ & $\begin{array}{l}\text { d. Occupa- } \\
\text { tion }\end{array}$ & f & $(\%)$ & e. Organization & $\mathbf{f}$ & $(\%)$ \\
\hline Male & 32 & 42.67 & $60-66$ & 1 & 1.33 & $\begin{array}{l}\text { High School } \\
\text { Graduate }\end{array}$ & 10 & 13.33 & $\begin{array}{l}\text { Government } \\
\text { Employee }\end{array}$ & 17 & 22.67 & $\begin{array}{l}\text { City } \\
\text { Government of } \\
\text { Cotabato }\end{array}$ & 5 & 6.67 \\
\hline \multirow[t]{8}{*}{ Female } & \multirow[t]{8}{*}{43} & \multirow[t]{8}{*}{57.33} & & 3 & 4 & College Graduate & 39 & 52 & $\begin{array}{l}\text { Private } \\
\text { Employee }\end{array}$ & 1 & 1.33 & CCSPC & 4 & 5.33 \\
\hline & & & & 4 & 5.33 & $\begin{array}{l}\text { Master's Degree } \\
\text { Graduate }\end{array}$ & 4 & 5.33 & $\begin{array}{l}\text { Business- } \\
\text { Related }\end{array}$ & 15 & 20 & Umpungan & 1 & 1.33 \\
\hline & & & $39-45$ & 6 & 8 & Vocational & 1 & 1.33 & $\begin{array}{l}\text { Sales Lady } \\
\text { / Vendor }\end{array}$ & 6 & 8 & MYRO & 1 & 1.33 \\
\hline & & & $32-38$ & 5 & 6.67 & \multirow{5}{*}{\multicolumn{2}{|c|}{$\begin{array}{l}\text { Others (College Lev } \\
\text { Under-graduate) }\end{array}$}} & \multirow[t]{5}{*}{28} & Volunteer & 1 & 1.33 & PASWI & 1 & 1.33 \\
\hline & & & $25-31$ & 23 & 30.67 & & & & Student & 16 & 21.33 & MAWAH & 1 & 1.33 \\
\hline & & & $18-24$ & 33 & 44 & & & & $\begin{array}{l}\text { Others (no } \\
\text { response) }\end{array}$ & 19 & 25.33 & AFP & 1 & 1.33 \\
\hline & & & & & & & & & & & & DND & 1 & 1.33 \\
\hline & & & & & & & & & & & & $\begin{array}{l}\text { No Organization } \\
\text { Membership }\end{array}$ & 60 & 80 \\
\hline TOTAL & 75 & 100 & & 75 & 100 & & 75 & 100 & & 75 & 100 & & 75 & 100 \\
\hline
\end{tabular}




\section{Effects of Martial Law Implementation to the Economy of Cotabato City}

Table 2. Frequency Distribution in Terms of Trades

\begin{tabular}{|c|c|c|c|c|c|c|c|}
\hline & \multirow{2}{*}{ Indicator } & \multicolumn{4}{|c|}{ Frequency } & \multirow{2}{*}{-Mean } & \multirow{2}{*}{$\begin{array}{l}\text { Descrip- } \\
\text { tion }\end{array}$} \\
\hline & & 4 & 3 & 2 & 1 & & \\
\hline 1 & Increased local market sales & 14 & 34 & 20 & 7 & 2.73 & High \\
\hline 2 & Improved sales efficiency & 14 & 38 & 21 & 2 & 2.85 & High \\
\hline 3 & Increased sales due to export expansion & 16 & 31 & 25 & 3 & 2.80 & High \\
\hline 4 & $\begin{array}{l}\text { Increased sales due to develop-ment of new } \\
\text { products and services }\end{array}$ & 16 & 41 & 15 & 3 & 2.93 & High \\
\hline 5 & Maintained reasonable price increase & 21 & 36 & 14 & 4 & 2.99 & High \\
\hline 6 & Increased fuel costs and utilities & 19 & 33 & 22 & 1 & 2.93 & High \\
\hline 7 & Increased sales due to exchange rate fluctuation & 12 & 34 & 27 & 2 & 2.75 & High \\
\hline 8 & Increased sales due to higher prices & 10 & 37 & 27 & 1 & 2.75 & High \\
\hline 9 & Increased registration of new trade ventures & 14 & 38 & 16 & 7 & 2.79 & High \\
\hline 10 & Increased consumer expenses & 14 & 40 & 19 & 2 & 2.88 & High \\
\hline & $\begin{array}{l}\text { Overall Mean } \\
\mathrm{n}=75\end{array}$ & & & & & 2.84 & High \\
\hline & Legend & & $\begin{array}{l}4.00 \\
-3.4 C \\
2.4 C \\
1.4 C\end{array}$ & & & $\begin{array}{l}\text { escripti } \\
\text { ery Hig } \\
\text { igh } \\
\text { ow } \\
\text { ery Loy }\end{array}$ & \\
\hline
\end{tabular}

As for the case of Cotabato City, despite the implementation of Martial Law, trades and investments were high. This implies that the government intervention during the given period was not too much as the economy of the city continue to thrive. This also shows that this Martial Law was primarily intended for security reasons and did not affect the trade and investment performance of Cotabato City. Instead, these aspects were increased since the law also provided a more secured environment promoting trade and investment activities.

Table 3. Frequency Distribution in Terms of Investments

\begin{tabular}{|c|c|c|c|c|c|c|c|}
\hline & \multirow{2}{*}{ Indicator } & \multicolumn{4}{|c|}{ Frequency } & \multirow{2}{*}{ Mean } & \multirow{2}{*}{$\begin{array}{l}\text { Descript } \\
\text { ion }\end{array}$} \\
\hline & & 4 & 3 & 2 & 1 & & \\
\hline 1 & $\begin{array}{l}\text { Increased number of commercial establishments } \\
\text { such as malls, restaurants, etc }\end{array}$ & 32 & 28 & 12 & 3 & 3.19 & High \\
\hline 2 & $\begin{array}{l}\text { Increased number of financial institutions such } \\
\text { as banks, remittance centers, etc }\end{array}$ & 18 & 34 & 20 & 3 & 2.89 & High \\
\hline 3 & $\begin{array}{l}\text { Increased transportation of local goods in and } \\
\text { out of the city }\end{array}$ & 14 & 36 & 22 & 3 & 2.81 & High \\
\hline 4 & $\begin{array}{l}\text { Increased industrial investments such as } \\
\text { processing and manufacturing facilities, etc }\end{array}$ & 14 & 30 & 25 & 6 & 2.69 & High \\
\hline 5 & Influx of foreign-funded investments & 17 & 26 & 25 & 7 & 2.71 & High \\
\hline 6 & Increased LGU and business investor partnership & 19 & 38 & 16 & 2 & 2.99 & High \\
\hline 7 & Increased sales on registered investments & 15 & 40 & 18 & 2 & 2.91 & High \\
\hline 8 & Newly opened establishments & 25 & 33 & 15 & 2 & 3.08 & High \\
\hline 9 & Sustained investment-friendly environment & 26 & 37 & 10 & 2 & 3.16 & High \\
\hline 10 & Clear investment policies & 19 & 37 & 14 & 5 & 2.93 & High \\
\hline & $\begin{array}{l}\text { Overall Mean } \\
n=75\end{array}$ & & & & & 2.94 & High \\
\hline
\end{tabular}


The respondents have recognized the increase in job openings, hiring rates in both government and private institutions, employee wages, and promotion opportunities. These were in contrast to the set-up during the Marcos Martial Law where there was a decline in the daily wages of workers. Moreover, opportunities that facilitate hiring of entrance-level employees were sustained through of Special Program for Employment of Students (SPES) and TESDA scholarships.

Table 4. Frequency Distribution in Terms of Local Employment

\begin{tabular}{|c|c|c|c|c|c|c|c|}
\hline & \multirow{2}{*}{ Indicator } & \multicolumn{4}{|c|}{ Frequency } & \multirow{2}{*}{ Mean } & \multirow{2}{*}{ Description } \\
\hline & & 4 & 3 & 2 & 1 & & \\
\hline 1 & Increased job openings or vacancies & 23 & 31 & 12 & 9 & 2.91 & High \\
\hline 2 & $\begin{array}{l}\text { Increased hiring rates on both government and } \\
\text { private institutions }\end{array}$ & 13 & 42 & 12 & 8 & 2.80 & High \\
\hline 3 & $\begin{array}{l}\text { Increased employee placements to government } \\
\text { and private offices }\end{array}$ & 19 & 33 & 16 & 7 & 2.85 & High \\
\hline 4 & $\begin{array}{l}\text { Increased hiring of Special Program for } \\
\text { Employment of Students (SPES) }\end{array}$ & 19 & 33 & 18 & 5 & 2.88 & High \\
\hline 5 & $\begin{array}{l}\text { Conduct of various trainings, seminars, } \\
\text { workshops for government and private } \\
\text { employees for skills enhancement }\end{array}$ & 18 & 33 & 19 & 5 & 2.85 & High \\
\hline 6 & Increased employment rate in Cotabato City & 25 & 30 & 13 & 7 & 2.97 & High \\
\hline 7 & $\begin{array}{l}\text { Increased employee salary/wage, compensation, } \\
\text { benefits or incentives }\end{array}$ & 25 & 23 & 20 & 7 & 2.88 & High \\
\hline 8 & $\begin{array}{l}\text { Increased worker retention in government or } \\
\text { private offices }\end{array}$ & 15 & 34 & 19 & 7 & 2.76 & High \\
\hline 9 & Increased promotion opportunities & 17 & 33 & 21 & 4 & 2.84 & High \\
\hline \multirow[t]{2}{*}{10} & Increased TESDA scholarship opportunities & 20 & 39 & 14 & 2 & 3.03 & High \\
\hline & $\begin{array}{l}\text { Overall Mean } \\
\mathrm{n}=75\end{array}$ & & & & & 2.88 & High \\
\hline
\end{tabular}

The high ratings provided by the respondents are supported by the continuing efforts of the Cotabato City Government particularly the City Tourism Office as local tourist destinations and products were promoted despite the period of implementation of Martial Law. Thus, the local employment and investment opportunities have also improved.

Table 5. Frequency Distribution Terms of Tourism

\begin{tabular}{|c|c|c|c|c|c|c|c|}
\hline & \multirow[b]{2}{*}{ Indicator } & \multicolumn{4}{|c|}{ Frequency } & \multirow[b]{2}{*}{ Mean } & \multirow[b]{2}{*}{ Description } \\
\hline & & 4 & 3 & 2 & 1 & & \\
\hline 1 & Increased arrival of tourists, both local and foreign & 17 & 29 & 25 & 4 & 2.79 & High \\
\hline 2 & $\begin{array}{l}\text { Increased tourism business ventures showcasing } \\
\text { locally-made products }\end{array}$ & 16 & 30 & 25 & 4 & 2.77 & High \\
\hline 3 & $\begin{array}{l}\text { Enhancement of natural scenic spots for additional } \\
\text { tourist sites }\end{array}$ & 17 & 28 & 26 & 4 & 2.77 & High \\
\hline 4 & Increased tourism sales & 17 & 34 & 20 & 4 & 2.85 & High \\
\hline \multirow[t]{2}{*}{5} & Increased tourism opportunities & 22 & 31 & 19 & 3 & 2.96 & High \\
\hline & $\begin{array}{l}\text { Overall Mean } \\
n=75\end{array}$ & & & & & 2.83 & High \\
\hline
\end{tabular}

As shown in Table 6, all indicators received the mean responses ranging from 2.83 to 2.94 with an overall mean of 2.87 described as High. Therefore, the respondents of this study 
agreed that the state of economy of Cotabato City during the implementation of Martial Law pursuant to Proclamation No. 216 is high.

Table 6. Summary of Mean

\begin{tabular}{rlrc}
\hline & Indicator & Mean & Description \\
\hline a. & Trades & 2.84 & High \\
b. & Investments & 2.94 & High \\
c. & Local Employment & 2.88 & High \\
d. & Tourism & 2.83 & High \\
\hline & Mean & $\mathbf{2 . 8 7}$ & High \\
\hline
\end{tabular}

\section{Problems Encountered during Martial Law Implementation}

As shown in Table 7, most of the respondents identified unstable political and social conditions as the top problems being encountered by the constituents affecting Cotabato City's state of the economy during the implementation of Martial Law. Though it has not affected the state of the economy of Cotabato City, too much political intervention or political problems are still perceived as factors that may affect the economy.

Table 7. Frequency, Percentage, and Rank Distribution of the Problems Encountered by Cotabato City Constituents on the Flow of Socio-Economic Related Activities during the Implementation of Martial Law

\begin{tabular}{llccc}
\hline \multicolumn{1}{c}{ Item } & Frequency & Percentage & Rank \\
\hline 1 & $\begin{array}{l}\text { Limited implementation of LGU economic projects } \\
2\end{array}$ & 16 & 21.33 & $6^{\text {th }}$ \\
& $\begin{array}{l}\text { Restriction in processing and registration of local and } \\
\text { foreign investments }\end{array}$ & 16 & 21.33 & $6^{\text {th }}$ \\
3 & Restricted project funding & 14 & 18.67 & $7^{\text {th }}$ \\
4 & Limited or controlled job hiring & 17 & 22.67 & $5^{\text {th }}$ \\
5 & Manipulation of commodity prices in contrast to the & 16 & 21.33 & $6^{\text {th }}$ \\
& suggested retail price (SRP) provided by the DTI & & & \\
6 & Employment hiring based on palakasan or backer system & 25 & 33.33 & $\mathbf{2}^{\text {nd }}$ \\
7 & Travel bans imposed on foreign tourists & 14 & 18.67 & $7^{\text {th }}$ \\
8 & $\begin{array}{l}\text { Limited processing on registrations of business } \\
\text { establishments }\end{array}$ & 18 & 24.00 & $4^{\text {th }}$ \\
9 & $\begin{array}{l}\text { Strict business application requirements } \\
10\end{array}$ & 24 & 32.00 & $\mathbf{3}^{\text {rd }}$ \\
11 & $\begin{array}{l}\text { Slow inflable political and social conditions } \\
\text { imposed by LGUs. }\end{array}$ & 26 & 34.67 & $\mathbf{1}^{\text {st }}$ \\
\hline
\end{tabular}

\section{CONCLUSSION}

Based on the findings of the study, it is concluded that the state of economy of Cotabato City is high during the implementation of Martial Law especially in terms of trades, investments, local employment and tourism. However, there is a need to address concerns on unstable political and social conditions, employment hiring based on palakasan or backer system. It is also concluded that business application requirements should be strictly implemented to improve the city's economy. 


\section{REFERENCES}

Organization for Economic Co-operation and Development (2004). OECD Principles of Corporate Governance. Paris. http://www.worldcat.org

Proclamation No. 216, s. 2017. Declaring a State of Martial law and Suspending the Privilege of the Writ of Habeas Corpus in the Whole Mindanao. May 23, 2017. 